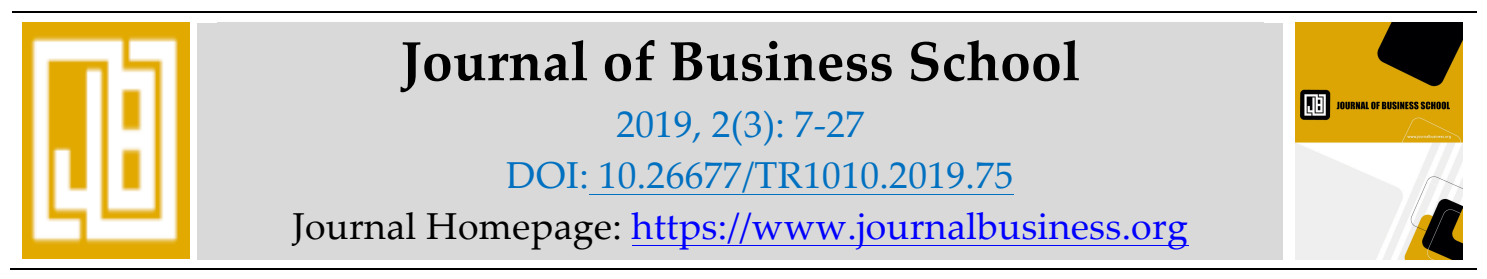

\title{
Impact of Fiscal Policy on Agricultural Productivity in Nigeria: An Empirical Analysis
}

OKOH, S.A.

Lecturers, Department of Economics, Federal University Wukari, Nigeria

AMADI, U.

Lecturers, Department of Economics, Federal University Wukari, Nigeria

OJIYA, E.A.

Lecturers, Department of Economics, Federal University Wukari, Nigeria

\author{
ANI, E.C. \\ Lecturers, Department of Economics, Federal University Wukari, Nigeria
}

\begin{abstract}
This study is designed to empirically examine the impact of fiscal policy on agricultural productivity in Nigeria between 199-0-2016. The research made use of secondary data obtained from the Central Bank of Nigeria statistical bulletin, Food and Agricultural Organisation (FAO) and the World Bank database. The study adopted econometric tools of analysis to empirically test the objectives outlined in the study. Empirical evidence revealed that all things being equal a rise in gross fix capital formation, agricultural credit and gross domestic product will lead to a corresponding increase in agricultural productivity respectively. Conclusively, the research holds that government total expenditure on agriculture and agricultural credit to the sector has no significant impact on agricultural productivity in Nigeria, while gross domestic product (economic growth) and investment by government in the area of roads, dams, irrigation and preservation have positive influence on productivity in the sector within the period under reference. In line with the foregoing conclusion, the following policy recommendations were made: government should put in place policy and modalities that will encourage existing banks (both commercial and agricultural banks) to make credit facility readily available to farmers to boost production in the sector; government should provide funds to acquire sophisticated farm tools (harvesters, tractors, herbicides, fertilizer etc) and as well build irrigation, dams, storage facilities and establish food processing industries across the country to enable farmers increase productivity, process and preserve their food stuff; government spending on agricultural sector must of a necessity be increased in line with global best practices as advocated by the United Nations agencies and other global organizations.
\end{abstract}

Keywords: Fiscal policy, economic growth; agricultural credit; cointegration 


\section{INTRODUCTION}

Agricultural development is one of the most powerful tools to end extreme poverty, boost shared prosperity and feed a projected 9.7 billion people by 2050. Growth in the agriculture sector is two to four times more effective in raising incomes among the poorest compared to other sectors. Agriculture is also crucial to economic growth. Similarly, in the words of Benjamin Franklin (1964), "There seems to be three ways for a nation to acquire wealth. The first is by war, as the Romans did plundering their neighbors. This is robbery. The second is by commerce which is generally cheating, the third is by agriculture, the only honest way, whereby a man receives real increase of the seed sown and grown from God. Agriculture entails the use of various inputs considered as resources to cultivate the land; produce crops like yam, rice, groundnut, beans, cocoa; forestry, livestock, including fishery, process and store, and distribute same.

According to Izuchukwu (2011), agriculture has been an important sector in the Nigerian economy in the past decades, and is still a major sector despite the oil boom. Basically, it provides employment opportunities for the teeming population, eradicate poverty and contributes to the growth of the economy. The oil boom of the 1970s led Nigeria to neglect its strong agricultural sector in favour of an unhealthy dependence on crude oil (Asoegwu and Asoegwu, 2007).

Fiscal policy means a policy pursued by a government to influence spending and economic activities in an economy by changing the size and content of taxation, expenditure and public debt. It is also a means or combination of revenue and expenditure, spending and saving and production and distribution (Ariyo, 1997). In the post oil boom era (1977 to 2002), the price of crude oil started falling and /or fluctuating and there has been a growing concern to revitalize the agricultural sector as well as diversify the economy. In order to revamp the agricultural sector, the federal government had embarked on and implemented several agricultural policies and programmes some of which are defunct or abandoned, and some restructured while others are still in place. These include the farm settlement scheme, national Accelerated Food Production (NAFPP), Agricultural Development Projects (ADPs), River Basin Development Authorities (RBDAs), National Seed Service (NSS), National Centre for Agriculture Mechanism (NCAM), Agricultural and Rural Management Training Institutes (ARMTI) and Agricultural Credit Guarantee Scheme Fund (ACGSF). Others were the Nigerian Agricultural Cooperative and Rural Development Bank (NACRDB) or Bank of Agricultural, Operation Feed the Nation (OFN), Green Revolution Programme, Directorate of Foods, Roads and Rural Infrastructure (DFFRI), Nigerian Agricultural Insurance Company (NAIC), National Agricultural Land Development Authority (NALDA), specialized Universities for Agriculture, Root and Tuber Expansion Programme (RTEP) and Rural Banking Scheme, etc. (Ugwu and Kanu, 2012). Furthermore, the Federal Government in 2004 launched another economic reform called National Economic Empowerment and Development Strategy (NEEDS) programme to encourage private sector participation in the development of the economy. It was also aimed at promoting growth and poverty reduction through a participatory process involving civil society and development partners. In the agricultural sector, NEEDS were directed to influence improvement in the production, processing and distribution of agricultural commodities.

\section{Problem Statement}

Despite the laudable programmes of the federal government, budget allocation to the agricultural sector remained poor until the coming in of former President Olusegun Obasanjo who made concerted efforts to revamp the sector. Productivity dropped 
significantly from 42 percent in 1990 to 34.6 percent in 2000, before rising to 56.5 percent and also falling to 52.4 percent in 2010 and the real per capital income is also in the decline while the contribution of agriculture to the total GDP has also declined from 40.33 percent in 1986 to 35.18 percent in 2010. Consequently, the country took the only easy way out, that is, borrowing to feed her populace. In short, the deplorable performance of agricultural sector in Nigeria for many years has rendered the country both a net importer of agricultural products and a debtor nation.

Besides oil, the major strength of the Nigerian economy is its agricultural resource base, its human resource base and its huge market. However, these agricultural resources have not been effectively mobilized so as to diversify the economy's revenue base and reduce dependence on oil. The economy remains vulnerable to external shocks emanating from fluctuation in the price of crude oil and the rising price of imports. The resulting external and internal imbalances are manifest in the adverse balance of payment position. Unemployment and low capacity utilization in virtually all sectors as well as deteriorating purchasing power of the populace (Bukar, Aliyu, Bakshi 1997). Moreso, the attitude of the banks in terms of making credit available to the farmers and the poor implementation of agricultural policies by the government which has led to the underdevelopment of the agricultural sector. On the basis of the above identified problems, this study attempts to critically examine the impact of Fiscal Policy on Agricultural Productivity in Nigeria. The broad objective of the study is to examine the impact of fiscal policy on agricultural productivity in Nigeria, with specific objectives to determine the impact of government expenditure on agriculture on agricultural productivity in Nigeria; ascertain the impact of agricultural credit on agricultural output in Nigeria and examine the effect of gross domestic product on agricultural productivity in Nigeria.

\section{LITERATURE REVIEW AND THEORETICAL FRAMEWORK}

According to Ahmed (1993), agriculture is been defined as the production of food and livestock and the purposeful tendering of plants and animals. He stated further that agriculture is the mainstay of many economies and it is fundamental to the socio-economic development of a nation because it is a major element and factor in national development. In the same vein, Okolo (2004) described agricultural sector as the most important sector of the Nigeria economy which holds a lot of potentials for the future economic development of the nation as it had done in the past. In the view of Fulginiti and Perrin (1998), agricultural productivity refers to the output produced by a given level of input(s) in the agricultural sector of a given economy. More formally, it can be defined as "the ratio of the value of total farm outputs to the value of total inputs used in farm production" (Olayide and Heady 1982). Notwithstanding the enviable position of the oil sector in the Nigerian economy over the past three decades, the agricultural sector is arguably the most important sector of the economy. Agriculture's contribution to the Gross Domestic product (GDP) has remained stable at between 30 and 42 percent, and employs 65 per cent, of the labour force in Nigeria (Emeka 2007).

\section{Agricultural sector in Nigeria and its performance}

Agriculture constitutes one of the most important sectors of the Nigerian economy. It is also a veritable tool in combating poverty in third world countries and achieving long-term economic development. Although Nigeria depends heavily on the oil industry for its budgetary revenues, the country is predominantly still an agricultural society with approximately $70 \%$ of the population engaging in agricultural production at a subsistence level. Based on the varying climatic conditions of regions and the vast and rich soil, the 
country produces varieties of crops while a significant portion of the agricultural sector in Nigeria involves livestock production, fishing, poultry, and lumbering, hence, agricultural products were major export product in the 1960s and early 1970s with the sector contribution to the GDP standing at 35\% in 2013 (CBN 2013).

Due to the sector's importance successive government has propounded policy programmes and strategies both monetarily and otherwise to revitalize agriculture in Nigeria from 1960 with all programmes aimed at increasing agricultural output for consumption and export, provide inputs and subsidies to small scale farmers, make credit facilities accessible to a large segment of rural farmers, eradicate poverty, create employment and raise the standard of living. These programmes included the Farm Settlement Scheme policy of 1959, the National Accelerated Food Production Programme (NAFPP) launched in 1972, the Agricultural Development Programme (ADP) of 1974 and 1989, Operation Feed the Nation (OFN) in 1976, the River Basin Development Authorities (RBDAs) wass launched in 1076, and the Green Revolution (GR) launched in 1980. The Directorate for Food Roads and Rural Women introduced in 1987, the National Agricultural Land Development Authority (NALDA), launched in 1992, the Family Support Programme (FSP) Family Economic Advancement Programme Strategy (NEEDE) launched in 1999, the National, Special Programme on Food Security (NSPFS) launched in 2002, the Root and Tuber expansion Programme (RTEP) launched in 2003, Seven Point Agenda of 2007 and Transformation Agenda of 2011.

According to the National Bureau of Statistics (2012), agriculture provided $41 \%$ of the country's GDP, with its contribution to the GDP dropping to 35\% in 2013 (CBN 2013). Today, less than 50 percent of the country's cultivable agricultural land is being cultivated with smallholder and traditional farmers who use crude agricultural tools cultivating most of this land. This has not been helped by the discovery of oil in the country. (Manyong et al 2003. The sector is bedeviled by problems such as organizational and weak policy, limited access to improved technologies in the form of improved seeds and the use of mainly crude farm tools such as hoes and cutlasses. Also, there are infrastructural inadequacies as the sector suffers from poor road network lack of storage/processing facilities and underfunding leading to the problem of high food importation.

Government has played a more dynamic role in agricultural production by ensuring stability of the financial system as well as guarantee sources of credit to the farmers through the manipulation of interest rate. Concessionary interest rate was given to the sector between 1970 and 1985. However, the SAP programme led to the deregulation of interest rates in 1990 and indirect monetary policy control was put in place. Hence agricultural sector has to compete for funding with the other sectors of the economy leading to the stoppage sectoral credit allocation policy (Gbosi 2005). This led to increased food import bills and hike in prices with food import increasing from $6.36 \%$ in 1991 to $27.02 \%$ and $30.56 \%$ in 1999 and 2011 respectively (NBS 2012). Due to the above negative impact of SAP and to safeguard the sector from competition as well as enhance flow of credit, the Agricultural Credit Guarantee Scheme (ACGS) was established in 1977 with the share capital of the ACGS increased from N199 million in 1977 to N3 million in 2001, in 2000, the Nigerian Agricultural Commerce and Rural Development Bank (NACRDB) was formed. The National Micro Finance Policy was also launched in 2006 with the aim of creating accessible and easy credit facilities to rural Nigerians. Also Agricultural Credit Support Scheme (ACSS) was established to provide credit facilities to farmer at single digit interest rate with a view to 
reduce the cost of agricultural production and increase output on a sustainable basis (Heineken \& Akorh 2013).

The effectiveness of these policies remained questionable as the interest rate remained high as well as inflation rate throughout the period. The average interest rate stood at $12.47 \%$ in 2010 and 2012 respectively (CBN 2012). Also, food inflation rose from $3.9 \%$ in 2006 to $8.2 \%$ in 2007 and $18.0 \%$ in 2008. It fell $15.5 \%$ in 2009 and $12.7 \%$ in 2010 (2012).

\section{The Concept of Fiscal Policy}

Fiscal policy refer to the part of government policy concerning the raising of revenue through taxation and other means and deciding on the level and pattern of expenditure for the purpose of influencing economic activities or attaining some desirable macroeconomic goals (Anyanwu, 1997:249). Fiscal policy simply defined is the manipulation of government revenue through tax system, government expenditure and debt management to achieve predetermined macro-economic objectives. Such fiscal policy can be used for allocation, stabilization and distribution. In essence, a primary objective of fiscal policy is to balance the use of resources of the public and private sectors and by so doing avoid inflation, unemployment, balance of payments pressures and income inequality. Fiscal policy is traditionally administered by the Executive arm through the Ministry of Finance.

According to Wise Geek (2013) the effectiveness of fiscal policy depends on a wide range of factors which cannot be reliably predicted or understood in advance. Behavioural changes caused by changes in government spending and taxation and among the most significant determinants of effective fiscal policy. Other factors affecting the effectiveness of fiscal policy as identified by Wise Greek include, time lag between the implementation of a new policy and the realization effects of that policy; the effects policy changes have on interest rates and other economic concerns; and the actual quality of the policy change. The goal of macro economy policy is to achieve target levels of inflation, unemployment and economic growth. Fiscal policy defines the scope and structure of services to be financed by the government, adjust the distribution of income through taxes and maintained stability of the economy so that these goals can be achieved if aggregate demand grows in pace with productive capacity. If aggregate demands does not expand more rapidly than productive capacity, inflationary pressures will increase.

On the other hand, if aggregate demand does not expand as much as growth of productive capacity in the economy, there will be rising unemployment. Although many analysts have argued that an important issue is the conduct of macroeconomic policy is the optimal policy mix-a combination of monetary and fiscal policies to achieve the objectives of macroeconomic policy. To them, the question of monetary-fiscal policy mix arises because both policies are interrelated and mutually reinforcing thus suggesting that they are complementary. Furthermore, the effectiveness of one depends on the other. The policy instrument for controlling demand is monetary policy which influences the supply of money and availability of credit and fiscal policy which affects the aggregate flow of purchasing power. Thus, aggregate demand can be influenced through the use of either fiscal or monetary policy. In fact, it is possible to achieve the same level of aggregate demand with different combinations of fiscal or monetary policies.

Monetary policy operates by changing money supply to affect indirectly the level of aggregate demand by changing the income available to spending units in the economy and its impact will depend on the nature of government spending i.e what goods government decides to by, what taxes it decides to charge and what amount decides to transfer. Any of these polices could affect the level of demand and cause an increase in consumption 
spending. Investment subsidy could also increase investment spending. The appropriate impact of fiscal policy depends very much on the state of the economy. Fiscal policy is expected to be expansionary, if expected level of demand is low and restrictive, if expected pressure and demand is high in the light of government objectives. An expansionary fiscal policy involving higher government spending can crowd out some interest sensitive private sector spending. In a recession, an expansionary monetary policy complemented by fiscal stimulus is required to stimulate growth, output and unemployment.

On the other hand, when an economy is over heated, tightening of fiscal and monetary policies is required. This assertion is in line with the Keynesian views of fiscal policy that expansionary and contracting fiscal policy can be used to influence macroeconomic performance. Musgrave and Musgrave (1989:6) identify the following as the objectives of fiscal policy; i. the provision of social goods, or the process by which total resource use is divided between private and social goods and by which the mix of social goods is chosen. They referred to this as allocation function ii. Adjustment of the distribution of income and wealth to ensure conformance with what society considers as "fair" or "just" state of distribution. This referred to as distribution function. iii. The use of budget policy as a tool for maintaining high employment, a reasonable degree of price level stability, and an appropriate rate of economic growth, with allowances for effects on trade and on the balance of payment. This is referred to as the stabilization function. From the above assertions it implies that the budgetary policy of a nation greatly determines the extent to which its macro-economic objectives are achieved. Thus, it can be postulate the there is a relationship between the budgetary policy of a nation an its economic growth and poverty reduction efforts.

\section{Fiscal Policy in Nigeria: Problems and Prospects}

Over the years, the fiscal policy has been the most important instrument influencing macroeconomic performance in Nigeria. The importance of having virile fiscal policies in Nigeria has continued to be the major focus of successive governments in Nigeria including the Obasanjo administration. In his 2001 independence day anniversary speech, President Obasanjo re-emphasis that the government in pursuance of a virile fiscal policy is sending a Bill (Fiscal Responsibility Bill) for an Act that would seek to strength the fiscal and monetary management at the national level. According to him, while all levels of government- local, state and federal have a joint responsibility for managing the nation's economy, the federal government must play a pivotal role in this regard for the benefit of all Nigerians, no matter where they reside. To him, the modest achievements have been eroded by what remains to be done despite government determined effort in the area of poverty eradication; too many of our citizens still remain poor.

Our industries are being revived and government has taken many measures to support them, but industrial capacity is still far below the level we will like to see. Inflation is still high with us, though today, it is not alarming as it used to be. All of us need to apply our collective will and resources so that every day, every year, we can look back and see how much more value we have added to our circumstances (Vanguard, 2002). Other problems include inefficient use of resources, waste and misplaced priorities in government expenditure, high fiscal deficits at all tiers of government, weak institutional structure among others. These problems have led to a heavy debt burden, huge recurrent expenditure, inefficient public service delivery etc. Also, government spent a huge proportion of current revenue in debt-servicing and interest payment. The Fiscal Responsibility Act is currently been implemented at the federal level with little result to show for it. The rate of corruption is still high and pervasive at the federal level and the virtue of transparency and 
accountability is been grossly abused and undermined by public officers. Furthermore, the budget process reached the point of near collapse before the democratic government came to power. The problem has to do with lack of political will and commitment to abide by stipulated rules and budget guidelines. As, such, it was difficult for the government to achieved their major fiscal objectives. Fiscal objectives are macroeconomic goals that the government intends to achieve using the various fiscal policies within a time period.

\section{Agriculture Sector and Economic Growth}

Several studies have focused on understanding the association between agriculture and economic growth, yet there is some disagreement. While some researchers have argued that agriculture should be the foundation of economic growth (Gollin, Parent \& Rogerson, 2002; Thirtle, Lin \& Piesse, 2003), others claimed that the linkages agriculture has with other sectors are too weak and its innovative structures inadequate for promoting economic growth (Ranis and Fei, 1961; Jorgenson, 1961).

However, the relationship between the agriculture sector and other sectors should not be a competition but rather be viewed as interdependent where supply and demand in sectors can be accommodated through strengthened linkages (Lewise, 1954). Nonetheless, the position of agriculture in the strive for industrialization should not be ignored as the case had been in Nigeria. As argued by advocates of agriculture-led growth (ALG), development of the agriculture sector is a prerequisite for industrialization through increase in rural incomes and provision of industrial raw materials, provision of a domestic market for industry and above all the release of resources to support the industry (Schultz, 1964;Timmer, 2004). Neglect of the agriculture sector in favour of the industrial sector will only lead to slow economic growth and inequality income distribution. Therefore, despite the fact that agriculture may be unable to singlehandedly transform an economy, it is necessary and sufficient condition in kick-starting industrialization in the early stages of development (Byerlee, Diao, \&Jackson, 2005).

The contributions of agriculture to economic growth can be examined through the roles of the sector in the economy. Johnston and Mellor (1961) summarized these roles in five intersector linkages; food, labour, market, domestic savings and foreign exchange. The most basic of these roles is, perhaps the supply of food for both domestic consumption and export. Direct contributions of food production can be through income generated from sales of farm produce and returns from economic activities related to production; or indirectly from increased capacity to partake in any form of economic activity through improved diet. Anyawu, Ibekwe and Adesope (2010) using correlation matrix find that production of major staples in Nigeria contributed significantly to GDP growth (except wheat) between 1990 and 2001. Also, as observed by Timmer (1995), the agriculture sector contributes to economic growth through provision of better caloric intake and food availability. The attainment of global food security and reduction of hunger hinges largely on this singular role. According to FAO (2005), the agriculture sector contributes to economic growth through provision of better caloric intake and food availability.

The attainment of global food security and reduction of hunger hinges largely on this singular role. According to FAO (2005), agriculture can facilitate the attainment of all 8 MDGs through the direct or indirect linkages to food availability and poverty reduction. In 2008 , UNDP reported that the $12.6 \%$ reduction recorded in the proportion of underweight 
children between 1990 and 2008 can be attributed largely to growth in the agriculture sector in Nigeria (NUDP, 2008). Furthermore, as population increases, failure to increase food supply in proportion to increased demand has negative effects on industrial profits, investment and economic growth (Johns \& Mellor, 1961).

Hazel and Roell (1983) assert that in the early stages of development, rising incomes of rural/farming households is essential to providing market for domestically produced goods and services via strengthened purchasing power. The most direct contribution of agriculture to economic growth, according to Irz et al. (2001), is increase in incomes of farmers and therefore their purchasing power. Results of several studies, including Gallup et al. (1997), Irz etal. (2001), show that an increase in agriculture growth results in an increase in the income level of the poorest of the population. Also results from cross-country regressions among developing countries show that $\$ 1$ increase in GDP results in significantly more poverty reduction when the growth is in agriculture rather than other sectors (Lipton, 2012). This sectoral growth increases the incomes and therefore purchasing power of farmers resulting in a vibrant domestic market for other sectors, hence growth in the economy.

An offshoot of income growth is increased domestic savings, both at micro and macro levels as observed in developed economies like Japan, Taiwan, south Korea, Hong Kong and recently, China (harbaugh, 2004). Agriculture therefore contributes to economic growth by increasing the incomes of majority of the population thereby strengthening their saving capacity. Results from and IFPRI publication on Ethiopia's growth and transformation plan shows that increased domestic savings is imperative to the achievement of higher Total Productivity (GTP) (Engida et al., 2011) finds that domestic saving is low among rural dwellers/farmers in Nigeria. He highlights the effect of high expenditure on food, which is a consequence of low income due to low productivity, on saving capacities of the farming households in study. This implies that domestic savings largely influences the growth path of the economy.

The sector is also in a position of making surplus labour available to industries. As productivity in the agriculture sector increase, surplus labour and capital is created and diverted to investment in industrial sector resulting in economic growth (Ike, 1982). This facilitates the industrialization process and eventually the transformation of the economy as postulated by the structural development advocates (Awokuse, 2008).

Having argued that economic growth in Nigeria depends to a large extent on growth in the agriculture sector, empirically investigating the sector's contributions to growth is important both to assess past efforts and justify future investment. Our empirical analysis in the next sections will be aimed at providing evidence on the sources of growth in the Nigerian economy. To further do justice to this, we will evaluate the agriculture sector by investigating the sources of its growth and the subsectors that require further attention based on already highlighted potentials relative to their past contributions.

\section{Theoretical Framework}

\section{Dependency Theory}

Dependency Theory has been presented as a theory of development that improves Modernisation Theory (Reyes, 2001a). It combines elements from a neo-Marxist theory and adopts a "revolution of under developed nations model". The focus of this theory is the totality of society and social system periphery, which highlights the differences between imperialistic countries in the first world and underdeveloped countries. Dependency theory explains these differences by focusing on regions and structural conditions in 
different nation states. Although the radical dependency outlooks of Andre Gunder Frank, Ruy Mauro Marinin, Thetono Dos Santos, and Immanuel Wallerstein, cited in Haque (1999), have the hue and revolutionary aspect of social change, they do not demonstrate the exact result of classical Moarxism or Leninism in their evaluation and consideration of historical development underdevelopment. For example, although Wallerstein applies Marxist terms like production mode, and challenges classes and state, he changes the order of the cause and effect relationship that originally was believed to exist among them form a Marxist viewpoint (Haque 1999, p. 111).

\section{Empirical Review on Agricultural Development in Nigeria}

There have been a number of valuable studies on the relationship between agriculture and economic growth. Oji-Okoro (2011) is of the opinion that agriculture agricultural production in the country. This implies that the more the public spending on agricultural sector, the more the improvements in the performance of the agricultural sector. Also, a large degree of change in agricultural output is accounted for by change in budgetary allocation to agricultural sector. Thus, budgetary allocation to agriculture has a large impact on agriculture output.

International Food Policy Research Institute (2008) wrote on public spending on agriculture in Nigeria (2001-2005). An empirical analysis was employed. Findings revealed that spending on agriculture was allotted to agriculture during 2001 to 2005, far lower than spending in other key sectors such as education, health, and water. This spending contrasts dramatically with the sector's importance in the Nigerian economy and the policy emphasis on diversifying away from oil, and falls well below the 10 percent goal set by African leaders in the 2003 Maputo agreement.

Nigeria also falls far behind in agricultural expenditure by international standard, even when accounting for the relationship between agricultural expenditure by international and national income. The spending that is an urgent need to improve internal systems for tracking, recording, and disseminating information about public spending in the agriculture sector.

Ariyo (1993) carried out an evaluation study on the desirability of Nigerian's fiscal profile between 1970 and 1990. The findings from this study suggest that the structures of government expenditure are inherently unsustainable by the country's resources profile. The major cause attribute to this was the phenomenal increase in government expenditure financed through debt raised from both internal and external sources. This has consequently led to persistent and unsustaninable annual deficits. The result also suggested that the structural adjustment programme (SAP) implemented in 1986 has so far not been of much assistance in addressing the problem.

\section{METHODOLOGY}

This study relied essentially on annual times series data of secondary nature sourced from the publications of the Central Bank of Nigeria (CBN) statistical bulletins, Food and Agricultural Organisation (FAO) and World Bank Development Indicators (WBDI) database.

Furthermore, the study is econometric based, hence multiple regression techniques such as Augmented Dickey Fuller Unit Root test for stationarity of variables, Johansen cointegration analysis for longrun relationship and Ordinary Least Squares regression for estimation of impact of the independent variables on the dependent variable. These econometric techniques through the use of Eviews version 8.0 shall be used in testing the hypotheses formulated for this study. 


\section{Variables in the Model}

Variables for this study are Agricultural Output (proxy for agricultural productivity) used as dependent variable with government expenditure on agriculture, investment proxied by gross fix capital formation, agricultural credit to farmers and gross domestic product as independent variables respectively. The time series data cover a 26 -years period ranging from 1990-2016. Agricultural / commercial credit, though not a fiscal instrument but is included in the model as a control variable to avoid the incidence of variable omission.

\section{Estimation Procedure}

The model of the study would be estimated with the aid of the E-view version 9.0 Econometrics package with Ordinary Least Squares (OLS) technique.

\section{Specification of the Model}

To examine the impact of fiscal policy on agricultural productivity in Nigeria using the Ordinary Least Squares (OLS) technique the following model is specified.

The functional form of the model is specified hereunder

Ag-output $=\mathrm{f}(\mathrm{G}-$ Exp-Agric, INVT, Ag-Credit, Gdp)

Eqtn 1

The mathematical form of the model is specified below

Ag-output $=\mathrm{f}(\mathrm{G}-$ Exp-Agric + INVT + Ag-Credit + Gdp $)$

Eqtn 2

The statistical form of the model is

Ag-output $=\beta_{0}+\beta_{1}($ G-Exp-Agric $)+\beta_{2}($ INVT $)+\beta_{3}($ Ag-Credit $)+\beta_{4}($ Gdp $) \quad \ldots$

Eqtn 3

In order to capture the stochastic term $\mu_{\mathrm{i}}$ of the variables, the explicit form of the models is given in econometric form below: Ag-output $=\beta_{0}+\beta_{1}(\mathrm{G}$-Exp-Agric $)+\beta_{2}(\mathrm{INVT})+\beta_{3}(\mathrm{Ag}-$ Credit $)+\beta_{4}(\mathrm{Gdp})+\mu_{t} \ldots$ Eqtn 4

The estimated models are further transformed into log-linear form. This is aimed at reducing the problem of multi-collinearity among the variables in the models. Thus the log-linear models are specified as shown below: $\quad$ LnAg-output $=\beta_{0}+\beta_{1}($ LnG-Exp-Agric $)+\beta_{2}$ (INVT) + $\beta_{3}($ LnAg-Credit $)+\beta_{4}(\operatorname{LnGdp})+\mu_{t} \ldots$ Eqtn 5

$$
\beta_{1}>0, \beta_{2}<0, \beta_{3}>0, \beta_{4}<0
$$

Where,

$\begin{array}{lll}\text { Ag-output } & = & \text { Agricultural Productivity } \\ \text { G-Exp-Agric } & = & \text { Government Expenditure on Agriculture } \\ \text { Invt } & = & \text { Proxy for Gross fix capital formation } \\ \text { Ag-Credit } & = & \text { Agric credit (proxied by credit to the private sector) } \\ \text { Gdp } & = & \text { Gross Domestic Product } \\ \mu_{\mathrm{i}} & = & \text { Stochastic or error term } \\ \mathrm{Ln} & = & \text { Natural logarithms } \\ \beta_{0} & = & \text { Intercept parameter } \\ \beta_{1-} \beta_{3} & = & \text { Coefficients } / \text { parameters }\end{array}$




\section{A priori Expectation}

(a) Agricultural Output (AG-output) and Government expenditure on agriculture: In $\beta_{1}$ above, the relationship is expected to be positive since the more government expenditure (funding) received by the Federal Ministry of Agriculture, the more capital projects like dam, harvesters, ploughs, irrigation and herbicides etc it can purchase towards strengthening the sector and ultimately leads to greater productivity/output.

(b) Gross fix capital formation is expected a priori to be positively related agricultural output. As government employs the fiscal policy instrument of investment in the agricultural sector, it is expected that roads, irrigation and dams etc built will increase the output from the sector.

(c) The relationship between Agricultural output and Agricultural Credit $\left(\beta_{3}\right)$ is equally expected to be positive. For the sake of clarity, agricultural credit refers to commercial bank loans / facility major from the Bank of Agricultural (BOA) extended to farmers to assist them engage in large scale farming / agricultural activities that has the potential of contributing to the economy.

(d) Gross Domestic Product implies the market value of all officially recognized final goods and services produced within a country in a given period. It is defined to include all final goods and services, that is, those that are produced by economic resources located in that nation regardless of their The relationship between the dependent and independent variable (AG-output and GDP), i.e. $\beta_{0}$ and $\beta_{2}$ is expected to be positive as well; since aggregate growth in national income contributes to growth in other sectors of the economy which agriculture is one.

\section{RESULTS AND DISCUSSION}

\section{Data Presentation}

Data used for this study were essentially sourced from the Central Bank of Nigeria (CBN) statistical bulletin and World Bank Development Indicators (WBDI). The data is presented for the Agricultural output (proxy for agricultural productivity) as dependent variable against G-Exp-Agric, GFCF, Ag_credit and GDP) as independent variables respectively.

\section{Table 4.1 Data Presentation}

$\begin{array}{rrrrrr} & \text { AG_OUTPUT } & \text { G_EXP_AGRIC } & \text { GFCF } & \text { AG_CREDIT } & \text { GDP } \\ 1990 & 9.21 \mathrm{E}+09 & 0.258000 & 14.42773 & 8.692986 & 2.82 \mathrm{E}+11 \\ 1991 & 8.11 \mathrm{E}+09 & 0.208700 & 13.79346 & 8.951905 & 3.29 \mathrm{E}+11 \\ 1992 & 7.66 \mathrm{E}+09 & 0.455975 & 12.80218 & 13.32934 & 5.55 \mathrm{E}+11 \\ 1993 & 5.12 \mathrm{E}+09 & 1.803806 & 13.61295 & 12.19857 & 7.15 \mathrm{E}+11 \\ 1994 & 6.68 \mathrm{E}+09 & 1.183291 & 11.19636 & 14.95410 & 9.46 \mathrm{E}+11 \\ 1995 & 8.81 \mathrm{E}+09 & 1.510400 & 7.083232 & 10.01618 & 2.01 \mathrm{E}+12 \\ 1996 & 1.05 \mathrm{E}+10 & 1.592562 & 7.303718 & 8.978995 & 2.80 \mathrm{E}+12 \\ 1997 & 1.18 \mathrm{E}+10 & 2.058885 & 8.372144 & 10.66127 & 2.91 \mathrm{E}+12 \\ 1998 & 1.20 \mathrm{E}+10 & 2.891705 & 8.619863 & 12.98141 & 2.82 \mathrm{E}+12 \\ 1999 & 1.22 \mathrm{E}+10 & 59.31617 & 7.011568 & 13.49416 & 3.31 \mathrm{E}+12 \\ 2000 & 1.17 \mathrm{E}+10 & 6.335779 & 7.031060 & 12.30446 & 4.72 \mathrm{E}+12 \\ 2001 & 1.43 \mathrm{E}+10 & 7.064546 & 7.593798 & 16.50936 & 4.91 \mathrm{E}+12 \\ 2002 & 2.78 \mathrm{E}+10 & 9.993554 & 7.020332 & 13.02111 & 7.13 \mathrm{E}+12 \\ 2003 & 2.80 \mathrm{E}+10 & 7.537355 & 9.913518 & 13.79619 & 8.74 \mathrm{E}+12 \\ 2004 & 2.94 \mathrm{E}+10 & 11.25663 & 7.401317 & 13.12077 & 1.17 \mathrm{E}+13\end{array}$


Journal of Business School, vol.2, issue.3, pp.7-27

$\begin{array}{llllll}2005 & 3.64 \mathrm{E}+10 & 16.32596 & 5.467015 & 13.22053 & 1.47 \mathrm{E}+13 \\ 2006 & 4.62 \mathrm{E}+10 & 17.91903 & 8.273721 & 13.16818 & 1.87 \mathrm{E}+13 \\ 2007 & 5.37 \mathrm{E}+10 & 32.48423 & 9.256423 & 24.57161 & 2.09 \mathrm{E}+13 \\ 2008 & 6.73 \mathrm{E}+10 & 65.39901 & 8.329817 & 33.65412 & 2.47 \mathrm{E}+13 \\ 2009 & 6.17 \mathrm{E}+10 & 22.43520 & 12.09461 & 38.34855 & 2.52 \mathrm{E}+13 \\ 2010 & 8.68 \mathrm{E}+10 & 28.21795 & 17.29074 & 15.39070 & 5.55 \mathrm{E}+13 \\ 2011 & 9.07 \mathrm{E}+10 & 41.20000 & 16.21198 & 12.46493 & 6.37 \mathrm{E}+13 \\ 2012 & 1.00 \mathrm{E}+11 & 33.30000 & 14.90769 & 11.78871 & 7.26 \mathrm{E}+13 \\ 2013 & 1.07 \mathrm{E}+11 & 39.43101 & 14.90391 & 12.58533 & 8.10 \mathrm{E}+13 \\ 2014 & 1.14 \mathrm{E}+11 & 36.70000 & 15.80270 & 14.48775 & 9.01 \mathrm{E}+13 \\ 2015 & 9.93 \mathrm{E}+10 & 41.27000 & 15.49010 & 14.19323 & 9.52 \mathrm{E}+13 \\ 2016 & 9.99 \mathrm{E}+10 & 76.75000 & 13.56780 & 15.64045 & 1.03 \mathrm{E}+14\end{array}$

Source: CBN, FAO and World Bank Database

Table 4.2 Time Series Properties

ADF Test Result for Log(AG-OUTPUT)

Lag Length: 0 (Automatic - based on SIC, maxlag=6)

\begin{tabular}{lccc}
\hline \hline & t-Statistic & Prob.* \\
\hline \hline Augmented Dickey-Fuller test statistic & -4.603170 & 0.0013 \\
\hline Test critical values: & 1\% level & -3.724070 & \\
& $5 \%$ level & -2.986225 & \\
& $10 \%$ level & -2.632604 & \\
\hline \hline
\end{tabular}

*MacKinnon (1996) one-sided p-values.

ADF Test Result for Log(G-EXP-AGRIC)

Lag Length: 0 (Automatic - based on SIC, maxlag=6)

\begin{tabular}{lccc}
\hline \hline & t-Statistic & Prob.* \\
\hline \hline Augmented Dickey-Fuller test statistic & -7.229830 & 0.0000 \\
\hline Test critical values: & $1 \%$ level & -3.724070 & \\
& $5 \%$ level & -2.986225 & \\
& $10 \%$ level & -2.632604 & \\
\hline \hline
\end{tabular}

*MacKinnon (1996) one-sided p-values.

ADF Test Result for $\log ($ GFCF)

Lag Length: 1 (Automatic - based on SIC, maxlag=6)

\begin{tabular}{lll}
\hline \hline & t-Statistic & Prob.* \\
\hline \hline Augmented Dickey-Fuller test statistic & -4.925794 & 0.0006 \\
\hline
\end{tabular}




\begin{tabular}{ccc} 
Test critical values: & 1\% level & -3.737853 \\
& $5 \%$ level & -2.991878 \\
& $10 \%$ level & -2.635542 \\
\hline
\end{tabular}

*MacKinnon (1996) one-sided p-values.

ADF Test Result for Log(AG_CREDIT)

Lag Length: 0 (Automatic - based on SIC, maxlag=6)

\begin{tabular}{lccc}
\hline \hline & t-Statistic & Prob.* \\
\hline \hline \multicolumn{2}{l}{ Augmented Dickey-Fuller test statistic } & -4.476779 & 0.0017 \\
\hline Test critical values: & 1\% level & -3.724070 & \\
& 5\% level & -2.986225 & \\
& 10\% level & -2.632604 & \\
\hline \hline
\end{tabular}

*MacKinnon (1996) one-sided p-values.

ADF Test Result for $\log (G D P)$

Lag Length: 0 (Automatic - based on SIC, maxlag=6)

\begin{tabular}{lccc}
\hline \hline & t-Statistic & Prob. $^{*}$ \\
\hline \hline Augmented Dickey-Fuller test statistic & -4.808561 & 0.0008 \\
\hline Test critical values: & 1\% level & -3.724070 & \\
& 5\% level & -2.986225 & \\
& $10 \%$ level & -2.632604 & \\
\hline \hline
\end{tabular}

*MacKinnon (1996) one-sided p-values.

Source: Author's Computation from Eviews 8.0

Interpretation of ADF Unit Root Result:

The result of the stationarity (Unit Root) test indicates that Agricultural output (proxy for agricultural productivity), government total expenditure on agriculture, gross fix capital formation (proxy for investment), agricultural credit and gross domestic product (GDP) respectively are stationary at first difference. None of the variables is stationary at level. Therefore, the null hypothesis of non stationarity of the variables in the model is rejected after differencing at the 1 percent and 5 percent level of significance. Having established the stationarity of the variables in the model, the next step is to conduct the Johansen cointegration test.

\section{Co-Integration Test:}

Co-integration test is conducted to determine if a long run relationship exist between the variables specified in the model in other to avoid the generation of spurious regression result. The result of the co-integration test is presented below:

\section{Table 4.2.2(a): Cointegration Rank Test (Trace)}

Unrestricted Cointegration Rank Test (Trace) 
Journal of Business School, vol.2, issue.3, pp.7-27

\begin{tabular}{ccccc}
$\begin{array}{c}\text { Hypothesized } \\
\text { No. of CE(s) }\end{array}$ & Eigenvalue & $\begin{array}{c}\text { Trace } \\
\text { Statistic }\end{array}$ & $\begin{array}{c}0.05 \\
\text { Critical Value }\end{array}$ & Prob. $^{* *}$ \\
\hline \hline None & 0.883781 & 103.2645 & 69.81889 & 0.0000 \\
At most $1{ }^{*}$ & 0.567006 & 49.45758 & 47.85613 & 0.0351 \\
At most 2 & 0.427166 & 28.53180 & 29.79707 & 0.0694 \\
At most 3 & 0.296527 & 14.60280 & 15.49471 & 0.0678 \\
At most 4 & 0.207360 & 5.809647 & 3.841466 & 0.0159 \\
\hline \hline
\end{tabular}

Trace test indicates 2 cointegrating eqn(s) at the 0.05 level

* denotes rejection of the hypothesis at the 0.05 level

${ }^{* *}$ MacKinnon-Haug-Michelis (1999) p-values

Unrestricted Cointegration Rank Test (Maximum Eigenvalue)

\begin{tabular}{ccccc}
\hline \hline $\begin{array}{c}\text { Hypothesized } \\
\text { No. of CE(s) }\end{array}$ & Eigenvalue & $\begin{array}{c}\text { Max-Eigen } \\
\text { Statistic }\end{array}$ & $\begin{array}{c}0.05 \\
\text { Critical Value }\end{array}$ & Prob. $^{* *}$ \\
\hline \hline None & 0.883781 & 53.80692 & 33.87687 & 0.0001 \\
At most 1 & 0.567006 & 20.92578 & 27.58434 & 0.2807 \\
At most 2 & 0.427166 & 13.92899 & 21.13162 & 0.3709 \\
At most 3 & 0.296527 & 8.793154 & 14.26460 & 0.3038 \\
At most $4{ }^{*}$ & 0.207360 & 5.809647 & 3.841466 & 0.0159 \\
\hline \hline
\end{tabular}

Max-eigenvalue test indicates 1 cointegrating eqn(s) at the 0.05 level

* denotes rejection of the hypothesis at the 0.05 level

**MacKinnon-Haug-Michelis (1999) p-values

Source: Author's computation from Eviews 8.0

In the two tables above, the result of the trace statistics (table 2a) and maximum Eigenvalue statistics (table $2 b$ ) revealed the rejection of the null hypotheses at $5 \%$ level of significance based on our decision rule. The result shows that there are at least two and one cointegrating equations or vectors among the variables of interest, meaning that there is a unique long run relationship between the variables within the period of study.

From the normalized equation (Ag-output) $f(G$-Exp-Agric $+A g$-Credit, GFCF + GDP), the Agoutput coefficient of 1.00000 indicates that the level of agricultural productivity (Ag-output) in Nigeria is 1 when other variables are zero. This shows that all things being equal gross fix capital formation, agricultural credit and gross domestic product will lead to a corresponding increase in agricultural productivity respectively. However, the coefficient of government total expenditure on agriculture revealed a negative and insignificant relationship with the dependent variable (agricultural productivity), showing that government expenditure in the agric sector has not yielded the desired outcome. 


\section{OLS Estimation Result}

The Ordinary Least Square (OLS) i.e. regression result is as presented below:

\begin{tabular}{crrrr}
\hline \hline \multicolumn{1}{c}{ Variable } & Coefficient & Std. Error & t-Statistic & Prob. \\
\hline \hline C & 5.614868 & 2.223298 & 2.525468 & 0.0193 \\
LOG(AG_EXP) & -0.067776 & 0.088397 & -0.766719 & 0.4514 \\
LOG(GFCF) & 0.415370 & 0.175816 & 2.362536 & 0.0274 \\
LOG(AG_CREDIT) & 0.247882 & 0.184401 & 1.344253 & 0.1926 \\
$\quad$ LOG(GDP) & 0.568947 & 0.081180 & 7.008419 & 0.0000 \\
\hline \hline R-squared & 0.945881 & Mean dependent var & 24.01802 \\
Adjusted R-squared & 0.936041 & S.D. dependent var & 1.045506 \\
S.E. of regression & 0.264410 & Akaike info criterion & 0.342945 \\
Sum squared resid & 1.538079 & Schwarz criterion & 0.582914 \\
Log likelihood & 0.370248 & Hannan-Quinn criter. & 0.414300 \\
F-statistic & 96.12730 & Durbin-Watson stat & 0.824996 \\
Prob(F-statistic) & 0.000000 & & \\
\hline \hline
\end{tabular}

Source: Author's computation from Eviews 8.0

The regression result above shows the impact of fiscal policy on Agricultural Productivity in Nigeria between 1990-2016. The goodness of fit of the model as indicated by an R-squared of 94 percent showed a good fit of the model. An adjusted R-Squared value of 94 percent indicated that the model fits the data well, the total variation in the observed behaviour of Agricultural output is jointly explained by variation in the explanatory variables. The remaining $6 \%$ is accounted for by the stochastic error term, i.e. from variables and other factors not captured in the model.

To test for the overall significance of the model, the ANOVA of the F-statistics is used. To test for the individual statistical significance of the parameters, the t-statistics of the respective variables were considered. The statistical test of significance of the model estimates is conducted by employing the student's t-test statistical analysis at five per cent significance level. The critical t-test value from the table is 2.021 . The decision therefore requires that the tabulated value be compared with the calculated value. If the critical value of the t-test is greater than the t-test calculated at five per cent significance level, the parameter estimated is statistically insignificant and vice versa.

From the analysis of this study, the variables (government agricultural expenditure and agric credit) which are the core variables meant to impact positively on the dependent variable were found to be statistically insignificant judging from their calculated t-test values of -0.766719 and 1.344253 respectively. The conclusion was reached because these values were all less than the threshold 2.021 critical value at $5 \%$ significance level set by theory. Only the coefficient of gross fix capital formation and gross domestic product was statistically significant in relation to the dependent variable in the model. It has a t-statistic value of higher than the table value of 2.021 .

The implication is that, only the coefficient of gross fix capital formation and gross domestic product was capable of bringing significant changes to agricultural productivity in Nigeria during the referenced period. The a priori expectations about the signs of the parameter estimates were also considered. Here, the coefficient of gross fix capital formation and GDP entered the model with a positive sign. Contrariwise, the coefficients of government total 
expenditure on agriculture and agricultural credit was inversely related to the dependent variable. By implication, a unit increase in investment and gross domestic product will increase agricultural productivity in Nigeria, while government expenditure on agriculture and agricultural credit coefficients variously indicated a lack of positive impact on productivity levels in Nigeria within the study period.

\section{CONCLUDING REMARKS}

This study focuses on the impact of fiscal policy on agricultural productivity in Nigeria between 1990-2016. The research made use of secondary data obtained from the Central Bank of Nigeria statistical bulletin, Food and Agricultural Organisation (FAO) and the World Bank database. The study adopted Augmented Dickey Fuller unit root test, Johansen cointegration test and Ordinary Least Squares Regression to empirically test the objectives outlined in the study. The output from the Augmented Dickey Fuller (ADF) unit root test revealed that all variables were found to be stationary at first difference. The Johansen Cointegration technique reveals the presence of two and one cointegrating equations respectively indicating the existence of a long-run equilibrium relationship among the series.

Empirical evidence revealed that all things being equal a rise in gross fix capital formation, agricultural credit and gross domestic product will lead to a corresponding increase in agricultural productivity respectively. However, the coefficient of government total expenditure on agriculture revealed a negative and insignificant relationship with the dependent variable (agricultural productivity), showing that government expenditure in the agric sector has not yielded the desired outcome.

Conclusively, the research holds that government total expenditure on agriculture and agricultural credit to the sector has no significant impact on agricultural productivity in Nigeria. On the other hand, gross domestic product (economic growth) and investment by government in the area of roads, dams, irrigation and preservation have positive influence on productivity in the sector within the period under reference.

The following is therefore recommended for policy implementation:

(a) The government should put in place policy and modalities that will encourage existing banks (both commercial and agricultural banks) to make credit facilities readily available to farmers to boost production in the sector.

(b) Government should provide funds to acquire sophisticated farm tools (harvesters, tractors, herbicides, fertilizer etc) and as well build irrigation, dams, storage facilities and establish food processing industries across the country to enable farmers increase productivity, process and preserve their food stuff.

(c) Government spending on agricultural sector must of a necessity be increased in line with global best practices as advocated by the United Nations agencies and other global organizations.

(d) Corrupt civil servants, contractors and bureaucrats who divert and misappropriate allocated funds for the growth of the sector must be punished to serve as deterrent to other would-be treasury looters. The various financial crimes commissions such as EFCC and ICPC should be strengthened to do this. 


\section{REFERENCES}

Abdullahi, A. (2003). Employment creation and opportunities in the agro-allied sub-sector: The case of cassava production. CBN Bullion Publication, 27(4), pp.10.

Abu, N. and Abdullahi, U. (2010). Government expenditure and economic growth in Nigeria, 1970-2008: A Disaggregated Analysis. Business and Economic Journal, 2010. BEJ-4.

Adetiloye, K. A. (2012). Agricultural financing in Nigeria: An assessment of the agricultural credit guarantee scheme fund (ACGSF) for food security in Nigeria (1978-2006). J Economics, 3(1), pp.39-48.

Ado, S.G. (2017). Agriculture: Panacea for Nigeria's economic recession. Invited Paper presented at the 22nd Ummah Convention held at Sultan Muhammad Maccido Institute for Qur'an and General Studies, Sokoto, April 15-17, 2017, 30pp.

Agricultural Economics 19: 45-51.

Agu, S.U., Okwo, I.M., Ugwunta, O.D. \& Idike, A. (2015). Fiscal policy and economic growth in Nigeria: Emphasis on various components of public expenditure. SAGE Open, October-December 2015: 1-12.

Ali, J. I., Jatau, S., \& Ekpe, M. J. (2016). Financial intermediation and agricultural output in Nigeria: An impact analysis of deposit money banks' credit. International Journal of Agricultural Economics, 1 (1), 16-25.

Alkali, R.A. (1997). The World Bank and Nigeria: Cornucopia or Pandora Box? Kaduna: Baraka Press.

Al-Yousif, Y. (2000). Does government expenditure inhibit or promote economic growth: Some empirical evidence from Saudi Arabia. Indian Economic Journal, 48(2)

and poverty reduction in Nigeria. CBN Bullion, 4, 23-56.

Anthony, E. (2010). Agricultural credit and economic growth in Nigeria: An Empirical Analysis. Business and Economics Journal, BEJ-14:1-7.

Anyanwu, J.C. (1997). Nigeria public finance. Onitsha: Joanee Educational Publishers Ltd.

Arthur, S. \& Sheffrin, S. M. (2003). Economics: Principles in Action. Upper Saddle River, New Jersey 07458: Pearson Prentice Hall.

Asoegwu, S. N. \& Asoegwu, A. O. (2007). An overview of agriculture mechanization and its environmental management in Nigeria. CIGR E-Journal, Invite Overview No 6. No ix May.

Awoke, M. U. (2004). Factors affecting loan acquisition and repayment patterns of small holder farmers in Ika North West of Delta State, Nigeria. Journal of sustainable agricultural resources, 9, pp.61-64.

Ayeomoni, I.O. and Aladejana, S.A. (2016). Agricultural credit and economic growth nexus. Evidence from Nigeria. International Journal of Academic Research in Accounting, Finance and Management Sciences, 6 (2), 146-158.

Bola, O. (2007). Nigeria Agricultural Sector, London: Oxford University Press.

Brickates, K. V. (2007). Plastics that is green in more ways than one. The Wall Street Journal 16 October. 
Central Bank of Nigeria (Various issues). Statistical Bulletin, Central Bank of Nigeria.

Central Bank of Nigeria. (Various issues). Annual Report and Statement of Accounts December. Abuja. Nigeria.

Chigbu, U.E. (2005). Agriculture as the only saviour to Nigeria dyeing economy. Retrieved on $4^{\text {th }}$ July 2017 from http://www.nigerianvillagesquare.com/articles/guest/2005/03/agricas-only-saviour-to.html

DFID (2005), Growth and Poverty Reduction. The Role of Agricultural Policy Paper, Ibadan University Press, Nigeria.

Dornbusch, R. \& Fischer, S. (1990). Macroeconomics (5th ed.) New York: McGraw-Hill Publishing Company. Economics. First Edition. Ibadan: Ibadan University Press.

Effoduh, O. (2014). The Economic Development of Nigeria from 1914 to 2014. Retrieved on $4^{\text {th }}$ July 2017 from $w w w . i n d p e n d e n t . a c a d e m i a . e d u$

Egwu, P. N.(2016). Impact of agricultural financing on agricultural output, economic growth and poverty alleviation in Nigeria. Journal of Biology, Agriculture and Healthcare, 6 (2), $36-42$.

Ejike R.D., Ohajianya D.O., \& Lemchi J.I. (2013). Agricultural credit risk and default management by banks in Imo State, Nigeria. Greener Journal of Agricultural Sciences, 3 (2), 137-144.

Ekanem, O. T. \& Iyoha, M. A. (1999). Microeconomic Theory. Benin City: Mareh Publishers.

Ekpo, A. \& Egwaikhide, F. (1994). Exports and economic growth in Nigeria: A reconsideration of the evidence. Journal of Economic Management, 1 (1), 100-115.

Ele, I.E., Okon, I.E., Ibok, W.O. \& Brown, I.N. (2014). Analysis of agricultural public capital expenditure and agricultural economic growth in Nigeria 1961-2010. American Journal of Experimental Agriculture 4(4), 443-456.

Emeka, O. (2007). Improving the agricultural sector toward economic development

Enete, A.A \& Taofeeq A. A. (2010). Challenges of agricultural adaptation to climate change in Nigeria: A synthesis from the literature. Journal of Field Action, 4.

Environmental Protection Agency (EPA) (2004). Human health issues. http://www.epa.gov/opp00001/health/human.htm

Evbuomwan, G. O. (2003), Agricultural Development: Issues of Sustainability, Contemporary Economic Policy Issues in Nigeria. Abuja: Research Department, Central Bank of Nigeria, pp.185-221.

FAO (2008). Hunger on the Rise. Food and Agriculture Organisation. Retrieved August 7, 2010 from http://www.fao.org/newsroom/EN/news/

Federal Government of Nigeria (2009). Commercial Agriculture Development Project: Project Implementation Manual (2009-2014). National Coordinating Office Of National Food Reserve Agency

Federal Republic of Nigeria (2000). Obasanjo's Economic Direction 1995-2003, Abuja: Office of the Honourable Minister for Economic Matters, Abuja, Nigeria. 
Freedman, D. A. (2005), Statistical Models: Theory and Practice. Cambridge: Cambridge University Press.

Fulginiti, L. and R. Perrin. 1998. "Agricultural Productivity In Developing Countries."

Garba, A. (2006). Alleviating poverty in Northern Nigeria. Being a Paper Presented at the Annual Convention of Zumunta Association at Minneapolis United State of America from July 28-29, 2006. Http://Www. Fao.Org/ Tc/Tca/Work05/Nigeria.Pdf

IFAD (2007). Rural Poverty in Nigeria: Agriculture in the Federal Republic of Nigeria. International Fund for Agricultural Development. Retrieved August 7, 2010 from http://www.ruralpovertyportal.org/web/guest

Iganiga, B. O. \& Unemhilin, D. O. (2011). The impact of federal government agricultural expenditure on agricultural output in Nigeria. Journal of Economics, 2(2), 81-88.

Igwe, A., Emmanuel, E.C. and Ukpere, W.I. (2015). Impact of fiscal policy variables on economic growth in Nigeria (1970-2012): a managerial economics perspective. Investment Management and Financial Innovations, 12 (2), 169-179.

Ijere, M. O. (1996). New Perspective in Financing Nigeria Agriculture. Enugu: Dimension Publishers.

Iyoha, M.A., Oyefusi, S.A, \& Oriakhl, D.E. (2003). An Introduction to Modern Macroeconomics Benin: Mindex Publishing

Izuchukwu, O. O. (2011). Analysis of the contribution of agricultural sector on the Nigerian economic development. World Review of Business Research, 1(1), pp.191 - 200.

Koutsoyannis, A. (1977). Theory of Econometrics: An introduction exposition of econometrics methods. Hampshire: Macmillan Press Ltd.

Lawal, A. A. (1997). The economy and the state from the pre- colonial times to the present. In Osuntokun, A. \& Olukoju, A. (eds.) Nigerian Peoples and Cultures, Ibadan: Davidson.

Madu, D.B; Gundiri, M.N; Musa, I.K; Nwa, E.U; Adamu, M.S; Bala, M.S; Jada, A; Musa, I.K \& Ogunniyi, E.O (2010). Country Profile-Nigeria. Abuja: Ministry of Water Resources.

Maduegwu, A. (2000). Growing up in Oguta: The economics of rural poverty in Nigeria. Africa Economic Analysis.

Manyong, V. M. (2003), Agriculture in Nigeria: Identifying opportunities for increased commercialization and investment. Being the Main Report of a Research funded by United States Agency for International Development (USAID) \Nigeria.

Medugu, N. I (2009). Nigeria: Climate Change - A threat to the country's development. Retrieved from http://www.allafrica.com/nigeria

Muftaudeen, O. O. and Hussainatu, A. (2014). Macroeconomic policy and agricultural output in Nigeria: Implications for food security. American Journal of Economics, 4(2), 99-113.

Nasir, A. S. D. (2016). The impact of Central Bank of Nigeria's agricultural credit guarantee scheme fund on agricultural and economic development of Nigeria. International Journal of Political Science and Development, 4 (3), 63-74.

National Bureau of Statistics (2015), 2015 Annual Performance Report of the Nigerian Economy, Abuja: The Presidency, National Planning Commission 
Nigerian Agricultural Insurance Scheme (1987). Operational Guidelines Lagos. Agricultural Finance Dept, CBN.

Nigerian National Planning Commission (2004): Meeting Everyone's Needs-National Economic Empowerment and Development Strategy, Abuja: Nigerian National Planning Commission

Nwachukwu, C. N. (2006). The history of agriculture in Nigeria from the colonial era to the present day: Pointing all agricultural programmes. Retrieved on 21 $1^{\text {st }}$ July 2015 http://www.onlinenigeria.com/articles/ad.asp?blurb=268

Nwankwo, O. (2013). Agricultural financing in Nigeria: An empirical study of Nigerian Agricultural Co-operative and Rural Development Bank (NACRDB): 1990-2010. Journal of Management Research, 5 (2), 28-44.

Nweke, F.I. \& Enete, A.A. (1999). Gender surprises in food production, processing and marketing with emphasis on Cassava in Africa. Collaborative Study of Cassava in Africa (COSCA) Working Paper No. 19. COSCA, IITA, Ibadan, Nigeria.

Nwosu, A. C. (2004). Private Sector Initiative in Agricultural Development in Nigeria. CBN. Proceedings of the $13^{\text {th }}$ Annual Conference of the Regional Research Unit. University of Ibadan, August 6 to 8, 2004.

Nwosu, F.O., Oguoma, N.N., Ben-Chendo, N.G., and Henri-Ukoha, A. (2010). The agricultural credit guarantee scheme fund: its roles, problems and prospects in Nigeria's quest for agricultural development. Researcher, 2, pp. 87-90.

Obasan, K. A. \& Adediran, O. A. (2010). The role of industrial sector in the economic development of Nigeria. Journal of Management and Society, 1(2), 09-16.

Ogboi, C. \& Oladipo, S. O. (2012). Stock market and economic growth: The Nigerian experience. Research Journal of Finance and Accounting, 3 (4), 103-110.

Ogen, O. (2004). Agriculture and economic development in Malaysia, 1960-1995: A viable model for Nigeria. Journal Economic and Financial Studies, Vol.1, No.1,

Ogiji, P. (2004), Reading in public finance and policy. Social Science Study group (SSSG) Monograph Series 1 (1), Makurdi: Kingdom Printing and Publishing Company Ltd.

Ogunyemi, O. I. Adedokun, A.S (2007). Annual budgetary allocation to agriculture and rural income distribution as veritable inputs for agricultural growth and development. Retrieved on $12^{\text {th }}$ July 2017 from www.unilag.edu.ng

Oji-Okoro, O. I. (2011). Analysis of the contribution of agricultural sector on the Nigerian economic development. World Review of Business Research, 1(1), 191 - 200.

Okanta, S. (2005), The role of fiscal policy in economic development: Nigeria in focus. Unpublished Lecture note, Department of Banking and Finance, Abia State University, Uturu.

Okolo, D. 2004. Regional Study on Agricultural Support, Nigeria's Case. FAO.

Okwori, J. and Sule, A. (2016). Revenue sources and economic growth in Nigeria: An appraisal. Journal of Economics and Sustainable Development, 7 (8).

Olayide, S.O. and E. O. Heady. 1982. Introduction to Agricultural Production

Olomola, A. S. (1997). Agricultural finance. In A.O. Philips and S.Tunji Titilola (eds.) NISER, Ibadan, 51-62. 
Olomola, A. S. (1997). Agricultural finance. In Philips, A.O., and Tunji-Titilola, S. (eds.) NISER, Ibadan, 51-62.

Olowa, O.W. \& Olowa, O.A. (2011). Issues, problems and policies in agricultural credit: A review of agricultural credit in Nigeria. Bangladesh E-journal of Sociology, 8 (2), 87-108.

Olowa, O.W. and Olowa, A.O. (2014). Policy interventions and public expenditure reform for pro-poor agricultural development in Nigeria. African Journal of Agricultural Research, 9(4), pp. 487-500.

Osinowo O.H. (2015). Effect of fiscal policy on sectoral output growth in Nigeria. Advances in Economics and Business 3(6), 195-203.

Raji, M. A. (2008). An analysis of the determinants of agricultural credit approval/loan size by commercial banks in South-Western Nigeria. Nigeria Agricultural Development Studies, 1(1), 17-26.

Sarris, A.H. (2004). The role of agriculture in economic development and poverty reduction: An empirical and conceptual foundation. http://inweb18.worldbank.org/ESSD/ardex.nsf/11ByDocName/Roleofagric.

Solomon, O. (2011). Evaluating the effect of fiscal and monetary policy on agricultural development in Nigeria. Retrieved on $12^{\text {th }}$ July 2017 from www.independent.academia.edu

Solomon, O. (2012). The impact of monetary policy on agricultural development in Nigeria. Retrieved on $12^{\text {th }}$ July 2017 from www.academia.independent.edu

Solomon, O. (2017). Agriculture expenditure and economic growth in Nigeria: An evaluation (1985-2016). Retrieved on 12 th July 2017 from www.academia.independent.edu

Timmer, C.P. (2003). Agriculture and pro-poor Growth. Retrieved on $21^{\text {st }}$ July 2005 from http://www.nric.net/poverty/pubs/timmer.pdf. 2003

Ugwu, S.D. and Kanu, I. O. (2012). Effects of agricultural reforms on the agricultural sector in Nigeria. Journal of African Studies and Development , 4(2), 51-59.

Ukeje, E.U. (2005). Modernizing small holder agriculture to ensure food security and Gender

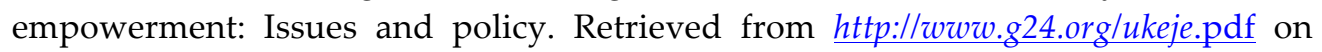
20th April 2015 